\title{
THE JUDICIAL PHILOSOPHY OF MR. JUSTICE MURPHY*
}

\author{
CHARLES FAHY $\dagger$
}

Justice Murphy was not one whose views were moulded significantly by years of judicial service and by the guidance and example of his associates on the Court. He came to the Court at full maturity, with views well formed by an extraordinary career-as attorney, law teacher, prosecutor, judge, chief executive of his city and state, Governor General of the Philippines, and Attorney General of the United States. The thinking reflected in his very earliest opinions carried through, with rare exception, to his last.

Further, he and his associates upon the Court during the last two decades have had thrust upon them the necessity of applying accumulated precedents to unusual and unforeseen circumstances. It is interesting to speculate whether their task was more difficult than that of earlier Justices whose decisions were unfettered by past pronouncements of the Court. Those of either period were trail-blazers and all contributed in their own way to the stability and strength of our institutions.

We should avoid the tendency to characterize Justice Murphy's philosophy by an easy generalization. ${ }^{1}$ It has been well said that great principles of constitutional law are not susceptible of statement in an adjective. Neither may the enduring work of exceptional Justices be catalogued by a label. This is especially important when we realize that the jurisdiction of the Court is selective. Only the most important and controversial issues come before it. Although division and dissent during Justice Murphy's tenure continued to lend vitality and integrity to the business of the Court, it is only fair to observe that the Court did not often divide on basic social and economic legislation, as in earlier cases such as Adkins v. Children's Hospital, ${ }^{2}$ Railroad Retirement Board v. Alton R. Co., ${ }^{3}$ or Labor Board v. Jones \& Laughlin. ${ }^{4}$ Although disagreements have been sharp and frequent in civil liberties cases, with Justice Murphy always supporting such rights to their "farthest reaches," the Court as a whole has been strong in protecting individual rights. The

*This article is a revision of a paper read at the Proceedings of the Bar of the Supreme Court in honor of Mr. Justice Murphy, March 6, 1951.

$\dagger$ Circuit Judge, United States Court of Appeals, District of Columbia Circuit.

1. Erroneously stereotyped as only a dissenter, Justice Murphy wrote often for the unanimous Court, as in his very first opinion, Tradesmen's Bank v. Oklahoma Tax Commission, 309 U.S. 560 (1940). In the great majority of decisions rendered during his years on the Court, he and his brethren agreed. Thus he contributed in full measure to the solid core of unanimous decisions which is the unifying force of our judicial system, bringing stability to so much of the law as it affects the nation as a whole.

2. 261 U.S. 525 (1923).

3. 295 U.S. 330 (1935).

4. 301 U.S. 1 (1937). 
search for a guiding philosophy naturally gives emphasis to rhetorical and didactic utterances, but these are typically found in opinions which turn not on clash of basic principle, but on differences as to the facts, or findings, or the setting of the particular regulation or order.

His opinions cover a variety of subjects-the commerce power in its numerous uses in regulating the manner of doing business, with its varying moral and economic characteristics; the administration of the criminal law, often including constitutional issues; the exercise of the war power; the administration of the naturalization laws; and, by no means least, civil liberties issues, sometimes cutting across other considerations because of their exceptional position in his concept of constitutional values.

In the end, I think, there is a philosophical thread traceable in a sufficiently large number of these cases in which the Court was not unanimous to justify the statement that his dominant thought was to prevent restraint upon individual liberty. Constitution, statutes, and other applicable principles of the law were to be interpreted and applied, if reasonably possible, to that end. Cases were not merely vehicles for the decision of a particular controversy, but occasions for the exposition of a philosophy of imaginative application of the Bill of Rights so that individual liberties should prevail over the efforts of the community to restrict them either by narrow construction of the rights themselves, oppressive use of authority, defects in trials, or uncertainty in statutory language. The case was rare indeed when any of his Associates could tax him with failure to give the fullest scope to the Bill of Rights. ${ }^{6}$

He took a broad view of the freedoms gained by the American Revolution, a narrow one of the authority of the state, through legislature, executive, or court, to restrict those liberties, however well intentioned the effort. He approached his task convinced that it is the duty of a Justice of the Supreme Court to remember always to hold sacred the place of dignity our founders accorded the individual.

Repeatedly this fundamental concern found forceful expression in those cases which involved the administration of criminal justice. He would confine the enforcement of penal statutes to areas clearly marked, leaving the individual free of restraint unless the statute plainly reached the questioned conduct. In the Classic case, ${ }^{6}$ the dissent in which he joined stated:

"It is not enough for us to find in the vague penumbra of a statute some offense about which Congress could have legislated, and then to particularize it as a crime because it is highly offensive. . . . Civil liberties are too dear to permit conviction for crimes which are only implied and which can be spelled out only by adding inference to inference." 7

5. Morgantown v. Royal Insurance Co., 337 U.S. 254, 264 (1949).

6. United States v. Classic, 313 U.S. 299 (1941).

7. Id. at 331,332 . 
Dissenting, again, in the Dotterweich case ${ }^{8}$ he invoked what Chief Justice Marshall had called "the tenderness of the law for the rights of individuals," to require for each person accused of crime, "an unequivocal warning from the legislature as to whether he is within the class of persons subject to vicarious liability." And in the Kraus case $^{9}$ his majority opinion applied the requirement of certainty to administrative regulations defining criminal responsibility.

Yet in his separate dissent in Screrws v. United States, where he spoke of the dignity of man "that is recognized and guaranteed by the Constitution," his desire to give concrete application to a broad Congressional policy led him to bring a particular situation within general language. The significant question in this case he thought was not the alleged failure of the statute "to warn the state officials that their actions were illegal"; rather, it was "whether law enforcement officers and those entrusted with authority shall be allowed to violate with impunity the clear constitutional rights of the inarticulate and the friendless." 10

This concern for the rights of the "inarticulate and the friendless," coupled with the liberty of the individual which he sought to hold to its largest limits, and the "rights of those who toil," cast him repeatedly in opposition to the Government's position in criminal cases. Here he spoke with the passion of the convinced crusader, at times going beyond the position of the most ardent defenders of civil liberties among his Associates. He would apply the search and seizure provisions of the Fourth Amendment to the utmost in protecting the privacy of the home ${ }^{11}$ or of words uttered "within the sanctity of private quarters."12 He would read into the Fourteenth Amendment all the protections of the Bill of Rights, without exception, and even go beyond their explicit requirements, ${ }^{13}$ especially when dealing with "lawlessness by officers of the law."14 His votes and opinions, in majority or dissent, on the last opinion day in which he participated (June 27,1949) show the depth of his convictions in defending what he regarded as the constitutional rights of the criminal at the bar.

But this concern for liberty was expressed in other contexts than criminal cases. In the long list involving the Jehovah's Witnesses he gave frequent voice to the breadth of freedom of speech and of religion imbedded in the First Amendment, even as applied to children. ${ }^{15}$ In his concurring opinion in Martin v. Struthers he stressed that "nothing enjoys a higher estate in our

8. United States v. Dotterweich, 320 U.S. 277, 286 (1943).

9. Kraus \& Bros. v. United States, 327 U.S. 614 (1946).

10. 325 U.S. 91, 135 (1945).

11. Trupiano v. United States, 334 U.S. 699 (1948).

12. Goldman v. United States, 316 U.S. 129, 141 (1942).

13. Adamson v. California, 332 U.S. 46, 124 (1947).

14. Wolf v. Colorado, 338 U.S. $25,41,46$ (1949).

15. Prince v. Massachusetts, 321 U.S. 158, 171 (1944). 
society than the right given by the First and Fourteenth Amendments freely to practice and proclaim one's religious convictions."16

A variant from this pattern of decision was his failure to join Chief Justice Stone's dissent in the first flag salute case. ${ }^{17}$ But shortly after, in the Barnette case he reversed his position, saying: "Reflection has convinced me that as a judge I have no loftier duty or responsibility than to uphold *** spiritual freedom to its farthest reaches."18 With the majority, he saw the protection of that spiritual freedom in the Everson case. ${ }^{10}$ The Court there upheld in substance the right of children attending a religious school, meeting state educational standards, to use public buses on the same terms as other school children. In the related $M c C$ ollum case ${ }^{20}$ he apparently agreed with the view that the facts showed state aid to religion in a manner inconsistent with the establishment of the religion clause of the First Amendment.

In upholding the constitutional rights of individuals accused of subversive beliefs, he evidenced his faith in the vitality of our free institutions to compete with political systems which he personally abhorred. In the Schneiderman case $^{21}$ involving the significant issue whether an avowed Communist was attached to the principles of the Constitution when he took his naturalization oath, Justice Murphy wrote for the majority, essentially basing his opinion on freedom of thought:

"We should let our judgment be guided so far as the law permits by the spirit of freedom and tolerance in which our nation was founded, and by a desire to secure the blessings of liberty in thought and action to all those upon whom the right of American citizenship has been conferred by statute, as well as to the native born."22

Again in the Bridges case he went beyond the majority opinion to hold the deportation statute unconstitutional on its face, saying that, "Only by zealously guarding the rights of the most humble, the most unorthodox and the most despised among us can freedom flourish and endure in our land."23 Both cases brought strong dissents from Chief Justice Stone, joined in each by other Justices. In the Schneiderman dissent particularly, Chief Justice Stone, long noted for his ardent support of civil liberties, powerfully argued from the record and the findings that the character of proved Communist affiliation is incompatible with the principles of the American Constitution. Though it is true the case might be said to have turned on an interpretation of the facts

\footnotetext{
16. 319 U.S. 141, 149 (1943).

17. Minersville School District v. Gobitis, 310 U.S. 586 (1940).

18. West Virginia State Bd. of Educ. v. Barnette, 319 U.S. 624, 645 (1943).

19. Everson v. Board of Education, 330 U.S. 1 (1947).

20. Illinois ex rel. McCollum v. Board of Education, 333 U.S. 203 (1948).

21. Schneiderman v. United States, 320 U.S. 118 (1943).

22. Id. at 120 .

23. Bridges v. Wixon, 326 U.S. 135, 157, 166 (1945).
} 
proved, Justice Murphy's civil liberties position was so deeply felt as virtually to set aside Congressional control over naturalization after citizenship had once been awarded. ${ }^{24}$

He wrote many opinions growing out of World War II. Repeatedly he declined to accede to wartime pressures or to military necessity, or to the claim of it, to justify limitations on civil rights. He joined in a restricted application of the statute defining sedition ${ }^{25}$ and of the constitutional definition of treason. ${ }^{26}$ His strong dissent in behalf of procedural rights of conscientious objectors under the Selective Service Act in the Falbo case ${ }^{27}$ no doubt influenced a later modification of the Court's position, in the Estep case. ${ }^{28}$ His concurring opinion in Duncan v. Kahanamoku, involving the validity of martial law in Hawaii, traced the historical background of the American opposition to military rule and insistence upon impartial trials by civil courts. "This supremacy of the civil over the military is one of our great heritages. $* * *$ Our duty is to give effect to that heritage at all times, that it may be handed down untarnished to future generations." ${ }^{29}$.He went even further in his dissents, finding denial of due process of law to the Japanese commanders Yamashita and Homma, convicted by military tribunals. ${ }^{30}$ His last vote as appears in the Court's Reports was a lone dissent against the ruling in the Hirota case, ${ }^{31}$ denying the Court's jurisdiction over the Japanese War Crimes Tribunal.

Perhaps the strongest language used in any of Justice Murphy's opinions was directed against the "racism" which he believed inherent in the wartime restraints on citizens of Japanese ancestry. Although concurring in the curfew restrictions on the West Coast, in the Hirabayashi case ${ }^{32}$ as of the time they were imposed, he dissented strongly in the Korematsu case, ${ }^{33}$ upholding the general evacuation of persons of Japanese ancestry. He concurred, of course, in the Endo ruling, taking the individual view that the detention of persons of Japanese ancestry regardless of loyalty was "another example of the unconstitutional resort to racism inherent in the entire evacuation program." ${ }^{34}$

24. The Schneiderman case needs comparison now with the more recent discussion in American Communications Assn. v. Douds, 339 U.S. 382, 424 et seq. (1950).

It is characteristic of Justice Murphy's views that his last opinion for the majority was rendered in Christoffel v. United States, 338 U.S. 84 (1949), and his last dissenting opinion was in Eisler v. United States, 338 U.S. 189, 193 (1949).

25. Hartzel v. United States, 322 U.S. 680 (1944).

26. Cramer v. United States, 325 U.S. 1 (1945).

27. Falbo v. United States, 320 U.S. 549, 555 (1944).

28. Estep v. United States, 327 U.S. 114, 132 (1946).

29. 327 U.S. 304, 324 (1946).

30. In re Yamashita, 327 U.S. 1, 26 (1946); Humma v. Patterson, 327 U.S. 759 (1946).

31. Hirota v. MacArthur, 338 U.S. 197 (1948).

32. Hirabayashi v. United States, 320 U.S. 81 (1943).

33. Korematsu v. United States, 323 U.S. 214, 233 (1944).

34. Ex parte Endo, 323 U.S. 283, 307 (1944). 
After the war, his concurring opinion in the Oyama case, ${ }^{35}$ striking down the Japanese land laws in California, epitomized his fundamental philosophy. $\mathrm{He}$ stressed in detail how the "fires of racial animosity" against Japanese had adversely affected our foreign relations. He invoked our adherence to the United Nations' Charter, with its pledge to promote respect for and observance of human rights and fundamental freedoms for all, without distinction. This, in his view, was but a reaffrmation of provisions of our own Constitution, which "embodies the highest political ideals of which man is capable."

While these examples from Justice Murphy's work on the Bench are illustrative of his distinctive approach, they by no means warrant the assumption that the protection from infringement of personal liberty was his sole concern. By the time he came to the Bench the Court had already resolved major controversies as to the authority of representative government, state or federal, to grapple with great economic and social problems. The Labor Act, the Fair Labor Standards Act, Social Security, and others, had been upheld. But continued controversies during the 1940's on the scope and effectiveness of much of this legislation furnished ample occasion for the expression of his position. It was natural that one of his convictions and experience would vote a full rein to the purposes of these reforms.

He was alert to prevent injustice in the social order, and to remedy abuses in the economic order. Where, as in the Public Utility Holding Company cases, he supported the basic constitutionality of one of the great reforms of recent times, he reaffirmed "the constitutional authority resident in Congress by virtue of the commerce clause to undertake to solve national problems directly and realistically, giving due recognition to the scope of state power. That follows from the fact that the federal commerce power is as broad as the economic needs of the nation."36 His opinions in these cases gave the widest scope to the concept of economic effects on interstate commerce. ${ }^{37}$

In his interpretation of labor legislation he accorded generous scope to the Wagner and the Fair Labor Standards Acts designed to ameliorate the conditions of workers. In his portal-to-portal decisions involving underground mine workers he stressed that, "We are not here dealing with mere chattels or articles of trade but with the rights of those who toil, of those who sacrifice a full measure of their freedom and talents to the use and profit of others." 38 In the $M t$. Clemens case ${ }^{39}$ he extended similar reasoning to the time necessarily spent by industrial labor generally on the employer's premises in preparing for productive work. The opinion was subjected to diverse constructions, aroused

35. Oyama v. California, 332 U.S. 633, 650 (1948).

36. American Power and Light Co. v. SEC, 329 U.S. 90, 103-4 (1946); North American Co. v. SEC, 327 U.S. 686, 700 (1946).

37. The concept was earlier expressed by the court in Wickard v. Filburn, 317 U.S. 111 (1942).

38. Tennessee Coal Co. v. Muscoda Local, 321 U.S. 590, 597 (1944).

39. Anderson v. Mt. Clemens Pottery Co., 328 U.S. 680 (1946). 
a storm of protest, and brought rapid Congressional clarification of employer liability, past and future. But it has wrought changes of lasting significance in enlarging the concept of compensable "work" in many subsequent contracts.

Another striking example of his thinking on labor relations is his first important opinion, Thornhill v. Alabama, 40 giving expression to a view suggested by $\mathrm{Mr}$. Justice Brandeis ${ }^{41}$ that making known the facts in a labor dispute was an aspect of free speech guaranteed by the First Amendment. Later he concurred in holding that industrial picketing is more than speech, may induce action irrespective of the nature of the ideas which are being disseminated, and may be prohibited in appropriate circumstances. ${ }^{42}$ Nevertheless the Thornhill doctrine has continued to figure significantly in majority and dissenting opinions in the recurrent and difficult applications of controls over industrial picketing by the several states. ${ }^{43}$ He thus sought the greatest possible usefulness of remedial legislation actually to help those sought to be helped.

But it is characteristic of his philosophy that his concern for the civil rights of individuals often asserted itself in limiting the scope of social and economic legislation, contrary to views strongly urged by labor unions, by executive and administrative agencies, or even by Justices long associated with his position on civil liberties. His opinion in the Virginia Electric case set aside an order of the Labor Board banning certain utterances by the employer, since the administrative findings had failed to raise "them to the stature of coercion by reliance on the surrounding circumstances." 44 Like concern for employers' civil rights led him to dissent in the Endicott Johnson and Oklahoma Press cases, 45 because he believed so strongly that the unrestrained exercise of subpoena power by non-judicial agencies was uncongenial to the individual's right of privacy. Notwithstanding that the constitutionality of the procedure had been upheld for many years, he insisted that confining the subpoena power exclusively to the judiciary was the only insurance against corrosion of liberty by over-zealous administrative agents. The majority, of course, stressed the practical necessities as well as judicial safeguards surrounding the exercise of administrative authority to obtain or examine books and papers. ${ }^{46}$

40. 310 U.S. 88 (1940).

41. See Senn v. Tile Layers' Union, 301 U.S. 468, 478 (1937).

42. See, e.g., Giboney v. Empire Storage Co., 336 U.S. 490 (1949).

43. See, e.g., Teamsters Union v. Hanke, 339 U.S. 470 (1950); Building Service Union v. Gazzam, 339 U.S. 532 (1950); and Hughes v. Superior Court, 339 U.S. 460 (1950).

44. NLRB v. Virginia Power Co., 314 U.S. 469, 479 (1941). The Board's new findings, after remand, satisfied him that the employer's freedom of speech had not been improperly abridged. Virginia Electric Co. v. NLRB, 319 U.S. 533 (1943).

45. Endicott-Johnson Corp. v. Perkins, 317 U.S. 501, 510 (1943); Oklahoma Press Publishing Co. v. Walling, 327 U.S. 186, 218 (1946).

46. Likewise, Justice Murphy would not apply the Fair Labor Standards Act to a newspaper publisher with only a small volume of interstate sales, Mabee v. White Plains Publishing Co., 327 U.S. 178, 185 (1946), although he had applied that Act 
Other notable instances of this approach by Justice Murphy to the problem of resolving the conflicting values of governmental policy and individual freedom are his dissents in the Associated Press ${ }^{47}$ case under the Sherman Act and in the National Broadcasting ${ }^{48}$ case under the Federal Communications Act. In these cases, he raised freedom of speech and press to such a doctrinaire level as virtually to question the capacity of all but the judicial branch to preserve our basic liberties-a concept he had himself vigorously rejected in many opinions upholding administrative and Congressional discretion. ${ }^{40}$

These illustrations from Justice Murphy's work by no means exhaust the range of his opinions and insight; but they should not be multiplied to the point where the thought beneath the words is lost in a confusion of instances. Enough has been said to demonstrate that he was not a servant of the law in the narrow sense of that term.

Throughout his opinions there runs the philosophy that the Constitution is not simply a charter of restraints on official action, including the courts. Rather, it embodies broad concepts and ideals which the Supreme Court particularly should faithfully mirror, by an expanding construction giving heed to "its historic purpose, its high political character, and its modern social and legal implications." $\mathrm{He}$ served at a time when the powers of government over the economic life of the individual were vastly enlarged; and he favored that growth. Yet, he consistently favored narrowing this power of government in matters vitally affecting the individual's freedom and procedural rights. All recognize that the civil liberties embodied in the Bill of Rights should have a very secure place in the hands of the judiciary. ${ }^{51}$ To Justice Murphy these rights were so precious a part of constitutional heritage that the Court should err in being "over-protective" of them. ${ }^{52}$ It was especially important that such rights be accorded the "worst of men" so that they will be available to the best of men in time of need. ${ }^{53}$ The position of the unpopular, the friendless and the despised was to him a challenge to our liberties, and their vindication in such cases was an expression of our strength and vitality as a nation.

broadly in many other circumstances to accomplish its basic purposes, apart from the portal cases, including many types of "local business" with varying and probably minor interstate effects. See, e.g., Addison v. Holly Hill Co., 322 U.S. 607 (1944) (dissenting opinion); Western Union v. Lenroot, 323 U.S. 490, 509 (1945) (dissenting opinion); McLeod v. Threlkeld, 319 U.S. 491, 498 (1943) (dissenting opinion). Also see 10 East 40th Street Co., v. Callus, 325 U.S. 578, 585 (1945) (dissenting opinion); Poland Electric Co. v. Walling, 326 U.S. 657 (1946) (concurring opinion); and Boutell v. Walling, 327 U.S. 463 (1946) (concurring opinion).

47. Associated Press v. United States, 326 U.S. 1, 49 (1945).

48. National Broadcasting Co. v. United States, 319 U.S. 190, 227 (1943).

49. See, e.g., Phelps Dodge Corp. v. NLRB, 313 U.S. 177, 200 (1941); SEC v. Chenery Corp., 332 U.S. 194 (1947).

50. Goldman v. United States, 316 U.S. 129, 136, 138 (1942).

51. See, e.g., Kovacs v. Cooper, 336 U.S. 77, 89, 106 (1949).

52. Jones v. Opelika, 316 U.S. 584, 623 (1942).

53. Goldman v. United States, 316 U.S. 129, 136, 142 (1942). 
He recognized, of course, that such freedoms were not absolute and must yield to the necessity of public order and national safety. That necessity was not demonstrated to his satisfaction in many instances already cited. The lessons of tyranny in our own history and in modern times abroad were in the forefront of his thinking. In the continuing search for equilibrium between liberty and order, he saw the fullest expression of liberty as the strongest bulwark of order, even when other Justices, equally ardent in defense of liberty, disagreed in particular cases.

It is part of the genius of our legal system that even great lawgivers are ranked below great judges whose application of basic law to new conditions gives it vitality beyond its original conception. Justice Murphy stands well forward among those who as members of the Supreme Court have applied their great talents, courage and devotion to the increase of individual liberty under law and to the amelioration of social and economic hardship. His place is secure. 


\begin{tabular}{lll}
\hline VoLUME 60 & MAY 1951 & NUMber 5 \\
\hline
\end{tabular}

\section{EDITORIAL BOARD \\ Stuart W. Thayer \\ Editor-in-Chief \\ Witraar R. Peritk Executive Editor}

Bernard H. Greene WIILIAIs DILL Rogers Comment Editors

\section{Patricia A. McGowan Case Editor}
BuRKE MaRshalL Article and
Book Review Editor

\author{
Daniel J. Freed \\ RICHARD N. GARDNER \\ ROBERT K. IIFTON
} Note Editors
Timothy ATKEson

WaLlace Barnes

Curtis J. Berger

Thonas F. BERgIN

EDWARD B. Bergaran

ROBERT ALAN BICKS

Clyde Bowles, JR.

JOEL L. CARR

James C. Cochrane

Paul U. Danter

WALTER G. FARR, JR.

HAROLD D. FIELD, JR.

Robert A. Fletcher

James B. Frankel

HowaRd I. FRIEDRLAN

Stanley J. FrIEdMaN

Josept Goldstein

Richapd N. GoldsTeIN

JUNIUS HorfaraN

HeNRY L. KING
JoHN S. Hoffinger Managing Editor

Robert P. LyoNs

Charles L. Mandelstam

Harold J. McComas

KURT W. MEICHIOR

AlaN Y. NAFTalin

Douglas S. Paliser

Charles A. Reich

Jeroure H. REICH

FREDERICK M. ROWE

Warren H. Saltzaian

Sherman G. Sass

HeNry C. Shayeivitz

EDWard F. SNYDeR

Howard Solomion

Paul S. Tenen

STEPHEN W. TUIN

George A. WeIss

FIULEN D. WENDORF

JOAN ZELDES

RICHARD A. ZUNIGA

Marte McMahoN

Business Secretary

Michael J. Lichtenstern Student Business Manager

Subscription price $\$ 5.50$ per year

This number, $\$ 1.00$

Canadian subscription price $\$ 6.00$ per year; Foreign, $\$ 6.25$ per year for prices on other isstues inquire

The Yale Law Journal, $401 A$ Yale Station, New Haven, Connecticut

\section{CONTRIBUTORS TO THIS ISSUE}

Fleming James, JR. B.A. 1925, LL.B. 1928, Yale University. Co-author, ShulMaN \& JaMres, CASEs on Torts (1942). LaFayette S. Foster Professor of Law, Yale Law School.

Roger F. PERRY. B.A. 1948, Harvard University, LL.B. 1951, Yale University.

Chartes FAHY. IL.B. 1914, LL.D. 1942, Georgetown University. Solicitor General of the United States, 1941. Formerly Legal Advisor to Department of State. Member of New Mexico and District of Columbia Bars. Judge, United States Court of Appeals for the District of Columbia. 